\title{
Complicating American Manhood: Marge Piercy's Woman on the Edge of Time and the Feminist Utopia as a Site for Transforming Masculinities
}

Michael Pitts

\author{
(2) OpenEdition \\ Journals \\ Electronic version \\ URL: https://journals.openedition.org/ejas/15771 \\ DOI: 10.4000/ejas.15771 \\ ISSN: 1991-9336 \\ Publisher \\ European Association for American Studies
}

Electronic reference

Michael Pitts, "Complicating American Manhood: Marge Piercy's Woman on the Edge of Time and the Feminist Utopia as a Site for Transforming Masculinities", European journal of American studies [Online], 15-2 | 2020, Online since 22 July 2020, connection on 08 July 2021. URL: http:// journals.openedition.org/ejas/15771; DOI: https://doi.org/10.4000/ejas.15771

This text was automatically generated on 8 July 2021.

Creative Commons License 


\title{
Complicating American Manhood: Marge Piercy's Woman on the Edge of Time and the Feminist Utopia as a Site for Transforming Masculinities
}

\author{
Michael Pitts
}

The cultural climate of the $21^{\text {st }}$ century United States is characterized by, among other ideological battles, conflicts between traditional conceptions of manhood and alternative masculinities posited to replace these patriarchal scripts. This conflict has escalated with the recent resurgence of patriarchal ideals of manliness. ${ }^{1}$ There is a resulting effort among masculinity scholars to develop feminist-oriented conceptions of manhood that may challenge and replace these patriarchal gender roles. These efforts frequently intersect with literary scholarship since they entail analyses of "representation and its connection with wider questions of change and continuity in contemporary, and in some more historical, masculinities and identities" (Edwards 3). Applying a similar approach at the intersection of masculinity studies and speculative fiction, this analysis utilizes contemporary American feminist utopias as a site for mining new masculinities. This project continues the work of scholars mining "theatre, film (narrative and documentary), literature, music, advertising, internet content, television, photography, politics, and current events-to posit questions about the processes of gender creation," but applies such an approach specifically to American science fiction (Shaw and Watson 1). In examining the fictional presentation of traditional and alternative masculinities in an influential feminist utopian novel, Marge Piercy's Woman on the Edge of Time (1976), this research locates new insights into the possibility of critiquing and transforming manhood. In her landmark text, Gender Trouble: Feminism and the Subversion of Identity (1990), Judith Butler sets out "to trace the way in which gender fables establish and circulate the misnomer of natural facts" (xxxiv). This analysis examines the ways feminist speculative authors such as Piercy, reversing the process Butler highlights, utilize their fiction to challenge naturalized, patriarchal conceptions of gender. 
2 Often cited alongside Joanna Russ, Ursula K. Le Guin, James Tiptree, Jr., and others as a central voice in 1970s feminist science fiction, Marge Piercy is a feminist poet, novelist, and recipient of the Arthur C. Clarke Award for science fiction. Her critiques of traditional masculinities and femininities exemplify Brian Attebery's description of a radical change in science fiction, making it "virtually impossible for an SF writer to take gender for granted any more" (Attebery 6). Piercy's novels such as Woman on the Edge of Time (1976) and He, She and It (1991) highlight the socially constructed and subjugating natures of gender roles, making them essential works at the intersection of masculinity studies and contemporary American science fiction. Her characters rebel against intersecting systems of oppression and, as a result, disrupt normative ideologies, especially those concerning gender. Woman on the Edge of Time, therefore, literally embodies "every ideal of the counterculture/Movement: ecological wisdom, community, androgyny, ritual, respect for madness, propertylessness, etc." ("Woman on the Edge of Time"). Among these revolutionary ideals is Piercy's presentation of new, egalitarian conceptions of masculinity. What she contributes to conversations at the intersection of gender and society, therefore, is a new conception of American manhood based upon connection, vulnerability, and equality that, as she illustrates, is germane to the utopian project and the betterment of contemporary American society.

Unlike their traditionally masculine counterparts, the new men populating Piercy's utopia value their feminine qualities and seek to eliminate the patriarchal order. Woman on the Edge of Time presents male and female characters who are characterized by and perform social functions traditionally deemed both masculine and feminine and are, therefore, androgynous. This aspect of the novel places it in contrast with Ursula K. Le Guin's The Left Hand of Darkness (1969), which is criticized for its presentation of biologically androgynous characters marked as men linguistically through the use of masculine pronouns and socially via their "roles which we are culturally conditioned to perceive as 'male"' (Anna 151). Piercy's male characters break from traditional gender scripts, offering alternative performances of manhood. In place of traditionally masculine desires for power and control, Piercy presents male characters focused on community, healing, connection, and fraternity.

4 Such new conceptions of manhood are positioned against the traditional masculinities of genre fiction: the so-called supermen. Ubiquitous in midcentury American speculative fiction, this character type, exemplified by characters such as Jommy Cross in A.E. van Vogt's Slan (1946) and John Pollard in Edward Hamilton's “The Man Who Evolved" (1931), is detached from societal concerns and, instead, focuses upon his own evolution and the possibility of consolidating power. Opposing the utopian project, he sees no value in "schools, governments, families, political groups, media," and other such communal organizations (Attebery 67). In contrast to the superman who "evolves apart from, or even in opposition to, his society," the men populating 1970s feminist utopias seek to nurture strong communal bonds and reject all hierarchical systems of power including racism, homophobia, and capitalistic patriarchy (Attebery 67). Catharine Stimpson implies as central to the novel these new male characters replacing the supermen of earlier speculative fiction when she states that the feminist utopia "has implored women and men alike, of all classes and races, to envision a social order" that takes as its ethical foundation "the profound liberty and freedom of each individual; the equality of individuals and groups; and the necessity of a balance between freedom and responsibilities, the autonomous self and the communal citizen, declarations of 
independence and interdependence" (3). Similarly, Donna Fancourt's identification of a "movement away from an emphasis on sexual difference, and towards a society that promotes connection with others" as central to feminist utopias hints at the necessity for men to undergo a paradigm shift in consciousness-a new masculinity-for society to be improved (109). Such a change in consciousness rejects the values of the traditional supermen of science fiction. Piercy, like Dorothy Bryant and Ursula K. Le Guin, rejects the traditional masculinities of earlier speculative fiction and replaces them with male characters performing new, utopian interpretations of manhood. ${ }^{2}$

Crucial to Piercy's depiction of these alternative masculinities and non-normative gender scripts more broadly is the way she imagines in each of her characters-both male and female-a combination of traits traditionally identified as feminine and masculine. In this way, she breaks from the trend among male writers to present visions of the androgyne in which a "masculine personality" is "fulfilled and completed by the feminine" (Annas 147). Pamela Annas groups "together loosely under the concept of androgyny" a range of examples "from visions of worlds which have entirely eliminated men and therefore sexual polarization, through visions of worlds which are biologically androgynous, to visions of worlds in which male and female functions and roles simply are not sharply differentiated" (146). Central to Woman on the Edge of Time is a vision of androgyny encapsulating these last two examples; in Piercy's novel, social and biological roles do not belong strictly to the categories of traditional masculinity or femininity. Instead, male characters balance traditionally masculine goals such as military service with their desires to raise and nurture a child. Female characters meanwhile occupy positions of social power and these roles showcase personality qualities traditionally labeled as masculine. Critics of androgyny as a tool in speculative fiction such as Jean Elshtain posit that "the full achievement of an androgynous world is possible only with the total elimination of sex roles" and the elimination of connections between biological sex and procreation (7). Piercy's presentation of androgyny and its attending genderqueer, alternative ideals of manhood is made possible through the utilization of technologies, such as the brooder, which allows reproduction without the need of a female host, and those developments allowing men to breastfeed, to differentiate reproductive roles. Piercy's vision of alternative masculinities, with its emphasis on technology and a more complex gender dynamic, illustrates, therefore, the radical nature of feminist utopias.

6 The structure of Piercy's novel adds considerable strength to its utopian message. Like Dorothy Bryant's The Kin of Ata Are Waiting for You and Ursula K. Le Guin's The Dispossessed, Woman on the Edge of Time follows a protagonist who travels between utopian and dystopian societies. Unlike these texts, which follow male citizens of dystopia and utopia, respectively, Piercy's novel centers the experiences of a disempowered female citizen of dystopia-the contemporary United States-as she experiences life within a drastically improved, feminist polity. Confined to a mental institution early in the narrative, Consuelo Ramos discovers she can communicate with people of the future and even travel mentally across space and time to explore their utopian community. The novel, like the novels of Bryant and Le Guin, interweaves utopian and dystopian passages in order to dramatically demarcate the differences separating patriarchal and feminist societies and the masculinities each nation normalizes. Central to this functioning of the novel and its presentation of contrasting utopian and dystopian performances of manhood is Piercy's use of time travel as a powerful literary device. Able to travel across time and therefore visit a future feminist 
utopia and patriarchal dystopia, the novel's protagonist, Connie, and the reader through her are prompted to compare three possible societies. The connections Piercy draws between the contemporary American dystopia and these two possible futures, a feminist utopia and a nightmarish patriarchal alternative, illustrate the binary struggle between two societies with antithetical feminine and masculine gender scripts.

The dystopian societies of the text, the United States in the present and a future version of the society in which the ideals of capitalistic patriarchy are taken to their extreme, are presented in tandem with those passages located in the future utopia. Piercy compels her reader to note the differences separating these polities by alternating, through the protagonist's ability to time travel, the setting of her novel from the dystopian to the utopian nation and vice versa. The qualities of this utopia, a future, collectivist anarchical community located in present-day Mattapoisett, Massachusetts, are, therefore, contrasted strikingly with those of these patriarchal alternatives. In this way, the structure of the novel and its intermingling of utopian and dystopian passages add considerable power to Piercy's gender analysis. This juxtaposition of nations parallels a contrast in traditional and new conceptions of manhood that produces the dialectic of masculinities central to Piercy's novel. Building upon "Mikhail Bakhtin's emphasis on the importance of generic heterogeneity as a source of dialogic" power, Keith Booker identifies as "an important source of energy for" Woman on the Edge of Time "the resultant dialogue between" these imagined utopian and dystopian nations visited by Connie (340). Just as the novel's contrast between these dystopian and utopian visions increases its power, its inclusion of traditional and alternative masculinities in opposition to one another intensifies the dialectic of the utopian text concerning gender.

8 The feminist qualities of this utopia reveal the significance of masculinities to Mattapoisett. Requiring of its citizens a balanced focus on community, interdependence, responsibilities, and an interest in equality, this idealized society compels attitudes absent from traditional masculinities and implies, therefore, a need for alternative conceptions of manhood. Karen Stein's claim that in the novel "it is necessary 'to make men over' as more sensitive and nurturing people so that they fit into the communal society" reiterates this common understanding of the way the text connects to issues of masculinity (129). ${ }^{3}$ As Stein outlines, "the people of this future have worked to create such consciousness" through, among other methods, education (130). In this polity, "young people are trained in meditation, and forms of mind control" and "their educational system strives to imbue all community members with values of caring and nurturance" (Stein 129). As Stein's analysis reveals, it is through these methods that masculinities are re-made.

Piercy's presentation of disruptive, future masculinities is unique in its "emphasis upon purposeful human action in bringing about utopia" (Somay 30). In the text, the direct tracing of the impact of present actions upon the future is made possible by Connie's time-traveling abilities. When the future is altered and Connie arrives not in Mattapoisett but instead in a patriarchal, dystopian New York, she and her utopian allies recognize a causative event in her own time: the development of a cognitive biotechnology enabling control of the mind and emotions. A wrongfully confined patient of the mental institution at which this tool is developed, Connie resolves to halt the research project. Concluding with Connie fatally poisoning the doctors spearheading this work, the novel offers to the reader as apparent the assurance that 
the utopian future is at least temporarily protected and that actions today will lead either to alternative masculinities and utopia or dystopia. Piercy presents her utopia as vulnerable to present actions and the influence of capitalism and the patriarchy.

This depiction of both future utopian and dystopian polities and their dependence upon events and characters in the present enables the novel to escape what is often considered a fatal flaw of utopian writing, its tendency toward the ahistorical and static. ${ }^{4}$ In the novel, Connie must choose between two possible futures, a feminist utopia and patriarchal dystopia. Prodding the reader to consider possible configurations of gendered societies and the possibility of influencing the development of such a future society in the present, Piercy radically re-envisions the utopian genre. Avoiding the tendency among traditional utopian writers to favor "over-arching theories of utopia as a distant or perfect world" and to thus fail to present "historically specific and situated alternatives" to socioeconomic ideologies, she presents a dynamic utopia connected to the historical setting of its audience (McBean 42). The power of the text is derived significantly from its inclusion of time travel as a means of critiquing masculinities and considering future dystopian and utopian societies alongside the society in which Connie resides, the contemporary United States.

11 Central to this presentation of the $20^{\text {th }}$ century United States is its tracing of the impact of intersectionality upon marginalized subjects such as Connie. In this way, the novel outlines those gendered networks of power that must be disrupted for new masculinities to be normalized. Through Connie's experiences, we see how interconnecting systems of sexism and racism work to marginalize and disempower the protagonist and others. The men with whom Connie comes into contact are either medical professionals or part of her social network. The men are positioned at varying distances from power and their contrasts reveal connections existing between intersectionality and masculinities. The doctors populating the novel in the $20^{\text {th }}$ century time frame, Redding, Morgan, and Acker, maintain powerful social and economic positions as educated, white, heterosexual performers of traditional masculinity. The men with whom Connie comes in contact outside the medical institution, mostly working-class men of color, on the other hand, wield less masculine authority due to their race and class positions.

12 The traditional masculinities of these men marginalized by class and race are informed by the concept of machismo. As demonstrated by Alfredo Mirande in Hombres y Machos: Masculinity and Latino Culture (1997), the understanding of this term and its performance is heavily influenced not "by region but by socioeconomic status" and therefore varies according to the social and economic positioning of its subscriber (77). As Piercy illustrates in the novel, a man such as Geraldo, the pimp of Connie's niece, Dolly, possesses little socioeconomic power and conceives of machismo "as exaggerated masculinity predicated on male dominance and authoritarianism, violence, aggressiveness, drunkenness, dumb, irresponsibleness, selfishness, stubbornness, and the unwillingness to back down for even the most trivial matter" (Mirande 77). In contrast, other men of color, such as Connie's brother Luis, who possess socioeconomic power and seek to pass as white in order to increase this amount of control, limit their public demonstrations of machismo since the application of this term "to Mexicans or Latino" by white men is "imbued with such negative attributes as male dominance, patriarchy, authoritarianism, and spousal abuse" (66). Machismo, therefore, is a type of hypermasculinity demonstrated by those men of color with whom Connie comes into 
contact in her personal life that, like its white masculine counterpart, exploits those marginalized further from power according to the logic of sexism, racism, and homophobia.

While prevented from fully accessing the power granted his white counterparts due to his ethnicity, Luis, for example, exercises complete control over those women in his life such as Connie. He experiences intersectionality as a financially successful, heterosexual man hindered by discrimination according to his race. He wields the power he has by subjugating those situated further from power. While "his anger and unruly pride" are "channeled into a desire to get ahead, to grab money, to succeed like an Anglo," he also directs this resentment toward those few people whom he is able to control, his family (397). Preoccupied, for example, with the appearances of his children and wife, Luis orders his son, Mark, to eat more in order to develop a masculine physique and baselessly accuses the women of the family, his daughter, Dolly, and wife, Adele, of being overweight. Besides these harsh, demeaning criticisms, the interactions between Luis and his family are controlled by him as a means of exercising that power denied him in contemporary American society: "He spoke quickly and he talked a lot and he didn't like interruptions" (383). Luis dominates his family, releasing upon them the anger he accumulates from his experiences in a systemically racist society.

This brutality is utilized by Piercy to reveal connections between traditional gender roles and intersectionality. Able to have his sister freed or confined indefinitely, Luis leverages this power, demanding that Connie perform traditionally feminine roles during a visit home he authorizes. Specifically, he demands that she perform domestic duties and refrain from offering her own opinion on matters during her stay. In this way, Luis takes advantage of a system that disenfranchises women and provides men power over them. Within patriarchy, male subjects who are not able to maintain the privileged hegemonic position are compelled to remain complicit to patriarchy, thereby benefiting "from the patriarchal dividend, the advantage men in general gain from the overall subordination of women" (Connell 79). Interlocking systems of oppression such as racism, sexism, and homophobia, therefore, affect both Connie and those men such as Luis whose identity markers distance them from hegemony but grant them power for their complicity to patriarchy.

The traditional masculinities of these marginalized men are characterized by desires to consolidate power and control over others and are informed by capitalistic, patriarchal socioeconomic systems and a sexist paradigm of consciousness. Shulamith Firestone's materialist critique of inequality among the sexes further illuminates the ways Piercy presents class, race, and gender as connected systems of oppression. Writing during the height of second wave feminism, Firestone provided in The Dialectic of Sex: The Case for Feminist Revolution (1970) an influential map for bridging Marxist and Psychoanalytic theories of inequality. The importance of this theory of sex and class in developing the utopian society is outlined in the novel by Bolivar, a male inhabitant of Mattapoisett: "'I guess I see the original division of labor, that first dichotomy, as enabling later divvies into haves and have-nots, powerful and powerless, enjoyers and workers, rapists and victims. The patriarchal mind/body split turned the body to machine and the rest of the universe into booty on which the will could run rampant, using, discarding, destroying"' (229). 

these connections and act as representatives of traditional masculinity, focused upon exercising power over others and attaining higher positions within socioeconomic hierarchies. The patriarchal, capitalistic men with whom Connie comes into contact throughout her personal life desire to have power and control over her, telling her "that what she" feels is "unreal and" doesn't "matter" (308). These traditionally masculine men meet the criteria for what Connie describes to the citizens of Mattapoisett as a real man: He "is supposed to be... strong, hold his liquor, attractive to women, able to beat out other men, lucky, hard, tough, macho we call it, muy hombre... not to be a fool... not to get too involved... to look out for number one... to make good money... You knuckle under to the big guys and you walk over the people underneath ..." (127). As Piercy notes in this passage, a man is identified by his ability to dominate and subjugate others according to the logic of capitalism, sexism, racism, and homophobia.

These dystopian patriarchal qualities permeate the institutions of the gendered nation and, more specifically, the medical establishment. In the novel, the nature of diagnosis and "how mental illness gets constructed-frequently based on stereotypical readings of surface characteristics such as behavior, age, poverty, body odors, or ethnicity-and is used as a form of social control" are implicated as forces of intersectionality (Martinson 53). The text illustrates, therefore, how traditional masculinities possess a mutually constitutive relationship not only with the nation but those institutions contained within its networks of power. As a result of prior experiences with hospitals, including the hysterectomy to which she was subjected, Connie recognizes this relationship between patriarchy and healthcare. She now "is much clearer about the connections between race, class, gender and the ease with which she is hospitalized as well as the justifications for the degree of control manifested in her treatment plan" (Martinson 62). The presence of intersectionality within contemporary American healthcare is most clearly illuminated by Piercy in her depiction of the rules governing the behavior of Connie and her fellow patients in these institutions and the treatments to which she is subjected.

Through the guidelines and treatments to which Connie is compelled to submit within these hospitals, Piercy outlines the toxic influence of traditional masculinities in health care. Female patients, for example, are expected to perform traditional femininities and are "punished for unladylike behavior" (156). While the use of explicit language is a punishable offence, "volunteering for every task defined as women's work, cleaning, sweeping, helping with the other patients, picking up clothes, fetching and carrying for the nurses" is rewarded with the allowance of greater personal liberties (369). Central to the treatment plans developed by these male doctors is the adoption by female patients of traditional gender roles and those unwilling to adopt these feminine roles are subjected to further domination and control. The increased severity of these treatments and their relationship to patriarchy are exemplified by the use of shock therapy: "A little brain damage to jolt you into behaving right. Sometimes it worked. Sometimes a woman forgot what had scared her, what she had been worrying about. Sometimes a woman was finally more scared of being burned in the head again, and she went home to her family and did the dishes and cleaned the house" (83). As Connie states, these shock treatments are repeated each time a female patient departs from the gender role assigned to her by the ideologies of traditional masculinity. Repeat 
offenders, or "shock zombies" as Connie calls them, are relocated to the back wards where they "lay, their brains so scarred they remembered nothing, giggling like the old lobotomized patients" (83). In this way, medicine as a traditionally male-dominated arena acts as a form of gender control and subjugation reinforcing patriarchy and centralizing control among traditionally masculine males.

Traditional masculinities seek to reinforce heteronormativity, exemplified in the hospitals' homophobic policies that harm queer patients. Connie's fellow patient and friend, Skip, for example, is identified as pathological due to his identification as a gay man. As Skip outlines, the harmful treatments imposed on these patients are the products of patriarchal desires to enforce heteronormativity: “'They don't like us, you know. We're lepers... You know what the last experiment was they pulled on me? They stuck electrodes on my prick and showed me dirty pictures, and when I got a hard-on about men, they shocked me"' (177). Subjected to a newly developed brain implant through which his desires and actions are manipulated, Skip eventually commits suicide in order to escape the control of this dystopian mental health institution. The patients Piercy presents are, therefore, imprisoned and subjugated in order to force upon them the logic of patriarchy and traditional conceptions of manhood.

A new neuroscientific and cognitive treatment plan makes possible the complete consolidation of power and control by these physicians over the minds and bodies of their patients. By implanting a new technological device in the brains of patients, these doctors are able to control their actions and emotional states, thereby imposing upon the minds and bodies of patients their own wills. These men seek to control and subjugate marginalized subjects such as Connie, desiring ultimately "to place in her something that would rule her feelings like a thermostat" via which they may dominate her will (310). In contrast to the technologies of Mattapoisett in which "mental resources incorporate a revalorization of embodiment, emotions and other subjugated knowledges-including dreams and even madness," this device empowers traditionally masculine men in places of power to control female bodies, restrict emotional experiences, and enforce the sanitized rationality they sanction as superior to the knowledges derived from embodied experience (Martinson 52). As outlined by Connie, they "believed feeling itself a disease, something to be cut out like a rotten appendix. Cold, calculating, ambitious, believing themselves rational and superior, they chased the crouching female animal through the brain with a scalpel" (308). As Connie recognizes, these men develop a tool enabling them to have complete control over the minds of women and to, therefore, enforce patriarchal values such as the distrust of disembodied knowledge upon them.

When she is eventually subjected to this treatment, Connie transforms into an image of traditional, hyperfeminine qualities, "an object. She went where placed and stayed there" (329). Piercy reveals in such a treatment plan how the interests of patriarchal masculinities are served by major institutions within the gendered nation, the contemporary United States. Pushed to the margins of power due to her sex, race, and class position, Connie faces the prospect of losing her very mind and body to those subscribing to traditional masculinities. Piercy, therefore, highlights in the novel those toxic elements of patriarchal visions of manhood that must be confronted for a new, egalitarian future to be possible. As she demonstrates, such a possibility is predicated upon the present. Failure to realize this ideal polity through activism in the present 
increases the likelihood of another, dystopian future characterized by traditional masculinities.

As Piercy reveals through Connie's visit to a hypermasculine, dystopian New York of a possible future, the toxic elements of the contemporary American capitalistic patriarchy lead to greater inequalities along the lines of class and sex among other identity elements. The hypermasculine nation Connie visits represents a possible future for societies increasingly predicated upon the domination and control of women. An unbridled patriarchy, the nation is a hyper-capitalistic society stratified according to race, class, and biological sex and controlled by an upper class living in isolation from the devastated and polluted ecologies of the Earth. As a dystopian possibility, it refracts those aspects Peter Fitting identifies as central to the utopian society of Mattapoisett: "(1) the basic living units developed as alternatives to the nuclear family; (2) the question of gender and the division of labor; (3) sexuality itself, both as an index to human fulfillment and in opposition to heterosexism and/or attempts to limit it to procreation" (165). In presenting a dystopian future that, in contrast, allows for familial and communal bonding only for the elite class, divides labor according to strict gender and class lines, and exploits working class women for their sexualities and reproductive functions within a heterosexist paradigm, Piercy intensifies the dialectic of masculinities central to this feminist utopia. The performances of manhood presented in this dystopian setting, therefore, are positioned in direct opposition to those alternative masculinities of Mattapoisett and this contrast induces in the reader a reconsideration of traditional gender ideologies.

These dystopian masculinities reject embodied knowledge and seek to consolidate power and control over the other. The two male characters described during Connie's visit, Cash and an unnamed guard, demonstrate such desires informed by patriarchal and capitalistic ideologies. Cash is the boyfriend and client of Gildina, a "contract girl" paid on retainer for sex. A type of substitute for the nuclear family, their relationship involves the contractual exploitation of Gildina. The dystopian performance of masculinity to which Cash subscribes is predicated upon the treatment of Gildina as a product to be purchased typically for the length of a month, consumed at his leisure, and discarded when these sexual experiences grow stale, at which point, she must locate a new partner at the risk of being identified as no longer desirable and, as a result, harvested for organs. While Gildina may sue if he breaks his contract, Cash and other men of his class position exercise almost complete control over such contracted women, placing them in isolation and under constant monitoring. Perhaps most conspicuously, this level of patriarchal control is reflected in the bodily alterations and appearances of these women. As Connie reflects, Gildina has "a tiny waist, enormous sharp breasts that stuck out like brassieres Connie herself had worn in the fifties--but the woman was not wearing a brassiere. Her stomach was flat but her hips and buttocks were oversized and audaciously curved. She looked as if she could hardly walk for the extravagance of her breasts and buttocks, her thighs that collided as she shuffled a few steps" (313). This role as a disempowered and enslaved sex worker and the other position available to women of Gildina's socioeconomic position, that of a mother who, as she explains, are designed or "cored to make babies all the time," reflect the centrality of traditional masculinities in feminist dystopias (316). Besides this focus on controlling and subjugating women, such conceptions of manhood are predicated upon the elimination of emotions and the rejection of embodied knowledge. 

silence emotional responses that could prevent them from fully adopting their hypermasculine social role. Gildina explains how Cash, whose name hints at the connection binding capitalism and patriarchy, underwent surgical alterations for this purpose: “'He's had SC, did you suppose on that?' 'What's escee?' 'Sharpened control, reallike. He's been through mind control. He turns off fear and pain and fatigue and sleep, like he's got a switch. He's like a Cybo, almost! He can control the fibers in his spinal cord, control his body temperature. He's a fighting machine, like they say" (324). As Vara Neverow outlines, embodiment "honors the unique subjectivity, physicality and agency of the individual in community" and is "linked to personal identity, to responsibility, to emotional health, to sensuality, to choice," (22). Incorporation, on the other hand, "is linked to the annihilation of the individual, to the hierarchical subordination of the subject to a conglomerate, to the obliteration of uniqueness, to the tyranny of uniformity" (Neverow 22). In this dystopian future, the traditionally masculine project of incorporation results in the annihilation of individuals complicit to it such as Cash. Able to submit the body to the control of the mind and eliminate embodied experience, Cash signifies toxic masculinity and is therefore positioned by Piercy against the utopian performances of manhood found in Mattapoisett. While the new masculinities of the utopian polity value communal selfreflection or "worming" as a method for analyzing subconscious biases, these dystopian conceptions of manhood value the cutting off of such reflections as the irrational, emotive products of the body over which the mind must triumph.

Through her sympathetic portrayal of a protagonist who seeks to disrupt the progress of mind-control experiments in the present to protect a future utopian society, Piercy emphasizes the importance of current actions to insure an ideal, feminist future. In highlighting the significance of traditional masculinities in both the dystopian future and present, she more specifically identifies the necessity of embracing alternative conceptions of manhood to impact the future. Foundational to Piercy's novel is the assumption "that the imagining of alternatives has a part to play in" the "profound social transformation" required to liberate humankind from "sexual oppression in our society" (Fitting 162). The outlining of these new ideals of manliness is central, therefore, to the project of imagining a new, egalitarian nation.

A central message of Piercy's novel is that such improved polities are characterized by alternative performances of manhood that reject ideologies of power and control. In the preface to the 2016 edition of the novel, Piercy identifies utopia as "born of the hunger for something better" and relying "on hope as the engine for imagining such a future" (xi). The utopian image of manhood she provides offers hope that such transformations of society and gender are possible. This new image of masculinity is inseparable from the utopian nation in which it is situated and, therefore, bears qualities that parallel this society, "an ideal 22nd-century utopia based on tolerance, nurturing, communality, ecological responsibility, and the complete effacement of conventional gender differences" (Booker 339).

Piercy presents in her male utopian characters new masculinities that, like the feminist utopia, value community and embodied knowledge. Bolivar, a utopian male, departs from traditional masculinities by seeking connection in order to heal emotionally. When his close friend, Jackrabbit, dies in battle, he initially suppresses his emotions in 
a typically traditional masculine style. Yet, during the funeral, he participates in a ritualistic dance with the healer, Erzulia, that releases his grief:

Erzulia possessed willfully by the memory of Jackrabbit led Bolivar round and round. He danced more feverishly, responding, his body became fluid and elegant as he had danced that night of the feast with Jackrabbit...The music ended and Bolivar embraced Erzulia. They stood a moment clasped and then Erzulia's body relaxed. Bolivar jumped back. 'But I felt per!' he cried out. 'You remembering,' Erzulia lilted gently, wiping her forehead. Bolivar crumpled to the ground in a spasm of weeping so sudden that for a moment no one moved to support him. Then Bee and Crazy Horse gently held him, murmuring. 'Good. At last your grief come down.' (345)

This scene presents aspects of new masculinities, specifically their interest in community and rituals of grieving and their acceptance of embodied knowledge, that contrast dramatically with the traditional ideals of manhood possessed by the male characters of the present and future dystopias. Cash, for example, represents later stages of patriarchal masculinities that seek increasingly more extreme methods, enabled by technology, for divorcing the mind from the body and the male from community. Similarly, men in the $20^{\text {th }}$ century United States such as Luis separate themselves from others and neglect social connections in order to avoid vulnerability and increase feelings of control and power. In contrast to these negative, traditionally masculine perceptions of embodied knowledge and community, the new men Piercy presents recognize the importance of such experiences and seek to cultivate meaningful connections with others.

These new gender conceptions replace isolation and the suppression of emotions with social connection and the expression of feelings. Central to this disruption of normative masculinities is community and vulnerability as tools for mourning and healing from a loss. Unlike the traditionally masculine desire to seek out isolation during times of grief, Bolivar and other utopian male subjects connect with others and strengthen community. Their openness to embodied knowledge and a new, community-oriented consciousness enables them to properly face their grief and express deeply felt emotions rejected by traditional masculinities. In this way, they contrast strikingly with the masculinities of the $20^{\text {th }}$ United States, which are characterized by a need among men to suppress emotion and seek separation from others during traumatic experiences. The new masculinities Piercy presents in Mattapoisett are marked by such interests in embodied knowledge and communal connection as well as the rejection of traditional desires to consolidate power and control.

A society seeking to eliminate hierarchical networks of power, Mattapoisett develops alternative masculinities. Contradicting the sociopolitical logic of the dystopian capitalistic patriarchies presented in the novel, the United States in both the present and possible future, it rejects capitalism and other interconnected rationales of subjugation such as sexism, homophobia, and racism. The new masculinities Piercy presents in Mattapoisett are posited as ideal yet imperfect performances of manhood that embrace a new paradigm of consciousness in which embodied knowledge and communal connection are valued while traditional desires to consolidate power and control are rejected.

31 The new masculinities of Mattapoisett are presented via those male characters with whom Connie comes into contact-Bee, Jackrabbit, Barbarossa, and Bolivar. Each of these characters demonstrates an openness to gender roles and sexualities absent from 
traditional masculinities. Barbarossa and Bee, for example, illustrate the influence of such new conceptions of manhood upon parenting. Bee is a "com" or co-mother to Innocente and shares these responsibilities with two partners, Otter and Luxembourg. A caring and involved parent, Bee shocks Connie with his open expression of emotions, crying during the "naming" ritual in which children are recognized as adults and choose new names for themselves after proving their ability to survive in the wild. The very name he chooses, "Innocente," illustrates his hope that in the future power structures valuing control and domination will be completely removed: "I'd been traveling for a year in Latin America. It made me brood about those centuries of the rape of the earth, the riches stolen, the brutalizing and starving of generations... toward that day when all trace of that pillaging will be healed... That's how you got named" (121). By allowing alternatively masculine interests in the elimination of power and control to influence the name he initially chose for the child and later recognizing that same child as an adult free to adopt a new name, Bee is disinterested in familial control and is representative of the new masculinities Piercy presents as central to the feminist utopia.

Barbarossa, who attends the "brooder" via which babies are born without the need for biological parents, is similarly positioned as an alternative to traditional masculinities. During their first encounter, Connie is disturbed by the technological advancements that have enabled men such as Barbarossa to take on one of the most significant roles of motherhood, nursing: "He had breasts. Not large ones. Small breasts, like a flatchested woman temporarily swollen with milk. Then with his red beard, his face of a sunburnt forty-five-year-old man, stern-visaged, long-nosed, thin-lipped, he began to nurse" (142). Focused upon the sustenance of these children and the "serene enjoyment" of such an intimate form of nurturing, Barbarossa, like Bee, illustrates the enriching capabilities of new masculinities (142).

An openness to diverse sexualities is another core principle of these alternative performances of manhood. Jackrabbit, a nineteen-year-old artist, illustrates this acceptance of and interest in alternative sexualities. Described by Luciente as one who "wants to couple with everybody," he is a queer character who performs a new masculinity in which other sexualities are accepted and respected (134). Involved with Luciente and Bolivar, he enjoys multiple relationships simultaneously and a range of sexual experiences. While Skip, a fellow patient of Connie's committed by his family because he is homosexual, is hospitalized, experimented upon, and eventually driven to suicide by his marginalization within a heteronormative patriarchy, Jackrabbit stands as an example of how such queer men may flourish within a new society in which alternative masculinities are valued.

As an anarchist society, Mattapoisett's aim is of "integrating people back into the natural world and eliminating power relationships" (Piercy ix). Such feminist interests are evidenced by its approach to medicine, education, agriculture, and government. In place of a medical establishment that exploits patients according to the logic of capitalism, patriarchy, and attending ideologies of subjugation, Mattapoisett possesses healers who practice naturalistic treatment approaches. Such healers do not resort to the removing of bodily organs but, instead, utilize their knowledge of the natural as well as technologies to treat the patient: “'We don't do much taking out. When we do, we regrow. We program the local cells. Slow healing but better after"' (170). In addition, they do not seek above all to extend life but teach instead to be accepting of 
death. As Susan Matarese points out, "Piercy seems to be suggesting...that a greater willingness to face up to our mortality and to recognize our shared vulnerability may be the basis for a dramatic transformation of human values and outlook" (107). Informed by the beliefs of "societies that people used to call primitive" but were "socially sophisticated," they reject traditionally patriarchal and coldly rational ideals in which life is prolonged and, instead, seek to comfort and enrich the experiences of each patient (132). This alteration is another product of the feminist paradigm shift in consciousness Piercy imagines. In presenting a "glimpse of the possibilities for social consciousness and community life" as the product of "a willingness to look at death more openly," Piercy includes as central to this social progress the advent of new, heathier masculinities opposed to patriarchal networks of power (Matarese 109).

The mental health institutions of Mattapoisett, in contrast to their dystopian counterparts of the present and future United States, value the autonomy and individuality of the patient and this also signals a departure from patriarchal societies marked by traditional masculinities. These institutions are described by Luciente as “"open to the air and pleasant"' (65). They "'are places where people retreat when they want to go down into themselves-to collapse, carry on, see visions, hear voices of prophecy, bang on the walls, relive infancy-getting in touch with the buried self and the inner mind"' (67). In the utopia, subjects such as Jackrabbit, who seeks such mental healing and sanctuary often, are not stigmatized for their needs and do so according to their own free will. In this way, the mental health institutions Piercy imagines in this utopia lack those interconnecting forces of subjugation typical of such organizations in the contemporary United States.

The absence of hierarchical perspectives in these alternative masculinities results in significant departures from the educational and governmental practices of the contemporary United States. Specifically, these institutions do not reinforce networks of power through the awarding of degrees or the granting of significant governing powers. Influenced significantly by a paradigm of masculinities not predicated upon domination and control, these institutions imprint upon the student and civil servant the meaningfulness of learning and community. Students, for example, are educated in their village prior to their naming ceremony. After this point, as Luciente explains, "we go wherever we must to learn, although only up to the number a teacher can handle. I waited two years for Rose to take me. Where you go depends on what you want to study. For instance, if I were drawn to ocean farming I'd have gone to Gardiners Island or Woods Hole. Although I live near the sea, I'm a land-plant person"' (53). Informed significantly by new, egalitarian masculinities, this utopian educational system replaces patriarchal approaches to learning-focused upon profit, social mobility, and competition-with one focused exclusively upon community, education, and the natural world.

Such alternative masculinities influence the governmental practices of Mattapoisett, which lack those capitalistic, patriarchal aspects of civil service common to the United States. The planning council for this township is made up of citizens chosen not by election but by lot, thereby preventing the development of a political class. In addition, the temporary nature of these positions, typically one year in length, and the absence of any social or economic promotion as a product of this role eliminate the possibility of hierarchical systems of power developing. In the next level of government, regional planning, "reps chosen by lot from township level go to the regional to discuss gross 
decisions. The needs go up and the possibilities come down. If people are chilled by a decision, they go and argue. Or they barter directly with places needing the same resources, and compromise" (162-163). Central to the governing practices of Mattapoisett is the voice of each citizen. The manner in which this polity removes socioeconomic influences protects it from the corrupting elements of capitalistic patriarchies. In place of such ideologies foundational to systems of power and control, Piercy imagines a utopian anarchy whose egalitarian system of government, predicated upon the elimination of power consolidation and subjugation, reflects those alternative masculinities central to this society.

Such new male gender scripts are reflected in the utopian community's nonexploitative approach to the environment. Demonstrating a non-patriarchal, dominating relationship to nature, Mattapoisett possesses several key qualities of an ecofeminist society: "nonhierarchical forms of organization, recycling of wastes, simpler living styles involving less-polluting 'soft' technologies, and labor-intensive rather than capital-intensive economic methods" (Merchant 295). In contrast to this feminist utopia are both the capitalistic patriarchy of Connie's present, the contemporary United States, and the dystopian vision of a future New York in which "multis" or multinational corporations have consolidated such power that the Earth has been stripped of its resources and is no longer inhabitable for life. By limiting the use of technologies to those dangerous or mundane tasks requiring completion, centering as the primary purpose of labor the enrichment of human lives in relationship both to each other and nature, and removing from agricultural industries the possibility to accumulate capital and market power, the citizens of Mattapoisett work to maintain a nation whose treatment of nature reflects its nonhierarchical conceptions of masculinity.

39 The key social organizations of Mattapoisett including its medical, educational, agricultural, and governmental institutions highlight the influence of masculinities upon national identity and the mutually constitutive relationship existing between gender and nation. The connections Piercy locates "among issues of racism, classism, sexism, and environmental abuse" strengthen both her critiques of contemporary American culture and the possibility she posits of moving toward a better society through the elimination of hierarchical perspectives central to traditional masculinities (Stratton 306). Presenting to her reader individual characters performing new, egalitarian masculinities, Piercy illustrates the methods by which men may work toward a better future through the introduction of new forms of manhood in the present.

The dialectic of masculinities Piercy provides and the manner in which the text prompts readers to consider the benefit of alternative ideals of manliness demonstrate Piercy's concern "with the liberatory dimension of the choices which people make in the present" (King 77). Explaining the necessity for contacting Connie, Luciente states, "'We must fight to come to exist, to remain in existence, to be the future that happens. That's why we reached you"' (213). In this feminist utopian novel, Piercy similarly outlines for her audience the necessity to adopt new masculinities qualified by a feminist paradigm of consciousness and a rejection of traditional desires to dominate and control. By presenting the possibility of such utopian masculinities as predicated upon the outcome of present discussions concerning gender and manhood, she calls for 
her male readers to recognize the urgent need to depart from traditional, patriarchal ideologies of masculinity.

Woman on the Edge of Time and its embedded commentary on gender are crucial to masculinity studies since the novel, as a female utopian narrative, enables audiences to imagine new, feminist-informed masculinities and recognize current societal mechanisms by which the patriarchal order functions. Defining narrative as "not restricted to literary and cultural artifacts but" extending "from the construction of individual gender identity by way of biographical, material and embodied social processes to collective national identities and images," Stefan Horlacher describes this communicative mode as crucial to conceptions of masculinity and the future of masculinity studies (5n14). Utilizing their own biographical, material, and embodied knowledge produced within the social processes of the patriarchal United States, Piercy and other feminist utopian authors construct invaluable, new gender identities for their male and female characters alike. The new conceptions of manhood they posit significantly enrich current masculinity studies scholarship and contribute to conversations surrounding the so-called crisis of masculinity in the $21^{\text {st }}$ century United States.

\section{BIBLIOGRAPHY}

Annas, Pamela J. "New Worlds, New Words: Androgyny in Feminist Science Fiction." Science Fiction Studies, vol. 5, no. 2, 1978, pp. 143-156.

Attebery, Brian. Decoding Gender in Science Fiction, Routledge, 2002.

Booker, M. Keith. "Woman on the Edge of a Genre: The Feminist Dystopias of Marge Piercy." Science Fiction Studies, vol. 21, no. 3, 1994, pp. 337-350.

Bryant, Dorothy. The Kin of Ata are Waiting for You. Evan Press, 1971.

Butler, Judith. Gender Trouble: Feminism and the Subversion of Identity. Routledge, 1990.

Connell, Raewyn. Masculinities. Allen and Unwin, 1995.

Edwards, Tim. Cultures of Masculinity. Routledge, 2006.

Elshtain, Jean. “Against Androgyny.” Telos, vol. 47, no. 4, 1981, pp. 5-21.

Fancourt, Donna. "Accessing Utopia through Altered States of Consciousness: Three Feminist Utopian Novels." Utopian Studies, vol. 13, no. 1, 2002, pp. 94-113.

Firestone, Shulamith. The Dialectic of Sex. William Morrow and Company, 1970.

Fitting, Peter. “'So We All Became Mothers': New Roles for Men in Recent Utopian Fiction.” Science Fiction Studies, vol. 12, no. 2, 1985, pp. 156-183.

Horlacher, Stefan. "Configuring Masculinity." Configuring Masculinity in Literary Theory and Practice, edited by Stefan Horlacher, Brill, 2015, pp. 1-10.

Kimmel, Michael. Angry White Men: American Masculinity at the End of an Era. Nation Books, 2017. 
---. Manhood in America: A Cultural History. Oxford UP, 2006.

King, Roger J. H. “Utopian Fiction as Moral Philosophy: Imagination and Critique." Utopian Studies, vol. 2, no. 3, 1991, pp. 72-78.

Le Guin, Ursula K. “American SF and the Other.” Science Fiction Studies, vol. 2, no. 3, 1975, pp. 208-210.

---. The Dispossessed: An Ambiguous Utopia. Harper \& Row, 1974.

Martinson, Anna M. "Ecofeminist Perspectives on Technology in the Science Fiction of Marge Piercy." Extrapolation, vol. 44, no. 1, 2003, pp. 50-68.

McBean, Sam. "Feminism and Futurity: Revisiting Marge Piercy's Woman on the Edge of Time." Feminist Review, no. 107, 2014, pp. 37-56.

McKenna, Erin. The Task of Utopia: A Pragmatist and Feminist Perspective. Rowman \& Littlefield, 2001. Merchant, Carolyn. The Death of Nature: Women, Ecology and the Scientific Revolution. Harper \& Row, 1989.

Mirandé, Alfredo. Hombres y Machos: Masculinity and Latino Culture. Westview Press, 1997.

Neverow, Vara. "The Politics of Incorporation and Embodiment: Woman on the Edge of Time and He, She and It as Feminist Epistemologies of Resistance." Utopian Studies, vol. 5, no. 2, 1994, pp. 16-35.

Piercy, Marge. He, She and It. Alfred A. Knopf, 1991.

---. Woman on the Edge of Time. Ballantine Books, 1976.

Seidler, Victor J. Transforming Masculinities: Men, Cultures, Bodies, Power, Sex, and Love. Routledge, 2006.

Shaw, Marc E. and Elwood Watson. "Introduction: From Seinfeld to Obama: Millennial Masculinities in Contemporary American Culture." Performing American Masculinities: The $21^{1 t_{-}}$ Century Man in Popular Culture, edited by Marc E. Shaw and Elwood Watson, Indiana UP, 2011, pp. $1-6$.

Somay, Bülent and R.M.P. “Towards an Open-Ended Utopia.” Science Fiction Studies, vol. 11, no. 1, 1984, pp. 25-38.

Stein, Karen F. "Inclusion and Exclusion in Some Feminist Utopian Fictions." Women's Utopian and Dystopian Fiction, edited by Sharon R. Wilson, Cambridge Scholars Press, 2013, pp. 112-132.

Stimpson, Catharine R. "Feminisms and Utopia." Utopian Studies, vol. 2, no. 3, 1991, pp. 1-6.

Stratton, Susan. "The Messiah and the Greens: The Shape of Environmental Action in Dune and Pacific Edge." Extrapolation, vol. 42, no. 4, 2001, pp. 303-316.

Waters, Alice E. “Hoping for the Best, Imagining the Worst: Dystopian Anxieties in Women's SF Pulp Stories of the 1930s." Extrapolation, vol. 50, no. 1, 2009, pp. 61-79.

“Woman on the Edge of Time." Kirkus Review, 7 May 2019, https://www.kirkusreviews.com/bookreviews/marge-piercy-7/woman-on-the-edge-of-time/.

\section{NOTES}

1. Two events are considered central in this recent reemergence of traditional masculinities and their attending crisis: the attacks on and events surrounding September 11, 2001 and, more recently, the 2016 U.S. election of Donald Trump. Victor J. Seidler in Transforming Masculinities: 
Men, Cultures, Bodies, Power, Sex and Love (2005) identifies events following September 11, 2001specifically the war in Iraq and the resulting protests across Europe-as exemplifying "a struggle that involved diverse global masculinities being locked into terrifying relationships with each other" (1). In an updated preface to Angry White Men: American Masculinity at the End of an Era (2017), Michael Kimmel highlights the importance of the Trump presidency to hegemonic masculinities: “Trump's election underscores" how "white men's anger comes from the potent fusion of two sentiments-entitlement and a sense of victimization" (x).

2. Though Le Guin's presentation of the androgyne in The Left Hand of Darkness is problematic, as previously outlined, her later work The Dispossessed (1974) successfully imagines new masculinities possessing qualities traditionally labeled both feminine and masculine. It is this later novel, the focus of my analysis in chapter 2, that serves as an example of Le Guin's depiction of new, transformed masculinities.

3. Erin McKenna locates a similar message in the novel, positing that "Woman on the Edge of Time not only presents a vision of an anarchistic society of the future, but... also focuses on the dangers of and need to get beyond violence, especially male violence" (69).

4. Alice Waters locates this dynamic aspect in both Woman on the Edge of Time and Moore's "Greater Than Gods" (1939). Woman on the Edge of Time, therefore, is situated within a tradition of feminist speculative writing in which utopian and dystopian narrative elements are utilized to express anxieties surrounding current, traditionally masculine, patriarchal networks of power and the possibility in the present of developing egalitarian gender ideologies and socioeconomic systems.

\section{ABSTRACTS}

Contemporary feminist utopias make up an overlooked site for mining new masculinities amidst the current so-called crisis of masculinity in American culture. What is often overlooked in analyses of feminist texts and more specifically feminist utopian fiction is how the alteration of femininity necessitates the transformation of masculine ideals. Such novels, while varying in their focus, are united by an interest in transforming patriarchal masculinities and replacing them with an alternative informed by second wave and intersectional feminism. Through an analysis of masculinities in one such utopia, Marge Piercy's Woman on the Edge of Time (1976), this essay traces how contemporary female speculative writers envision and propose new masculinities that, in opposition to their patriarchal counterparts, reject hierarchical perspectives and instead value equality, fraternity, and freedom.

\section{INDEX}

Keywords: science fiction, gender, utopia, dystopia, masculinities, Marge Piercy, feminism, genre fiction. 


\section{AUTHOR}

\section{MICHAEL PITTS}

Michael Pitts, a recent Ph.D. graduate of the University of Arkansas, has accepted a position as assistant professor at the University of South Bohemia in the Czech Republic. His research interests are positioned at the intersection of gender theory, speculative fiction, and utopia studies. 